\title{
Iron and Orange Extract on Hemoglobin among Anemic Pregnant Women in Nusa Tenggara Barat in 2018
}

\author{
Shinta Novelia*, Ariati Dewi, Sri Melinasari, Retno Widowati, and Bunga Tiara Carolin \\ Universitas Nasional, Jl. Sawo Manila, Pejaten, Ps. Minggu Jakarta 12520, Indonesia \\ *Corresponding author: shinta.novelia@civitas.unas.ac.id
}

Type of the Paper (Article)

Received: July 15, 2020; Accepted: July 25, 2020; Published: August 13, 2020

https://doi.org/10.29253/achnr.2020.2830

\begin{abstract}
Iron deficiency is the most common pathologic cause of anemia among pregnant women. Pregnant women with clinically significant iron deficiency may present with fatigue, weakness, pallor, tachycardia, and shortness of breath. An intervention is needed to improve hemoglobin among anemic pregnant women. This study aimed to analyze the effect of iron with orange extract on hemoglobin among anemic pregnant women in the Brang Rea health centers, Sumbawa Barat Regency, Nusa Tenggara Barat Province in 2017. The design was a quasi-experimental study. The population was 30 pregnant women who were anemic at the Brang Rea health center. A total population was used for sampling technique. Thirty anemic pregnant women were divided into the experiment and control group without randomization. The data were analyzed using descriptive statistics and inferential statistics. The results showed that there was a significant difference in hemoglobin before and after the intervention $(\mathrm{p}=0.001, \mathrm{t}=-21.1)$, and there was a significant difference in hemoglobin between the experimental group and the control group $(\mathrm{p}=0.001, \mathrm{t}=5.19)$. Consuming iron, together with orange extract, could increase hemoglobin among anemic pregnant women. Nurses and midwives need to share health education about the way to consume iron to prevent anemia among pregnant women.
\end{abstract}

Keywords: anemia, pregnant women, iron, orange extract, vitamin C

\section{Introduction}

Iron deficiency is the most widespread nutritional deficiency in the world. It is the most common cause of anemia among pregnant women (Haider, Olofin, Wang, Spiegelman, Ezzati \& Fawzi, 2013). Overall, the prevalence of iron deficiency in pregnant women in the United States was 18\%, with anemia in $5 \%$ of pregnant women and rates of iron deficiency increasing across trimesters from $6.9 \%$ to $14.3 \%$ to $28.4 \%$ (Mei et al., 2011). Beside iron deficiency, others factor related to anemia among pregnant women are malaria, hookworm infection, and schistosomiasis; micronutrient deficiencies including folic acid, vitamin A, and vitamin B12; and genetically inherited hemoglobinopathies such as thalassemia (Stevens et al., 2013), Iron deficiency may lead to maternal morbidity through effects on immune function with increased susceptibility or severity of infections, poor work capacity and performance and disturbances of post-partum cognition and emotions (Ekiz, Agaoglu, Karakas, Gurel \& Yalcin, 2005; Beard et al., 2005). 
Clinical trials of prenatal iron supplementation have shown improvement in hemoglobin (Hb) concentration. A study revealed that supplementation may improve maternal hematologic indices (Cantor, Bougatsos, Dana, Blazin \& McDonagh 2015). Anemia is defined by $\mathrm{Hb}<110 \mathrm{~g} / \mathrm{l}$ in the first trimester, $<105 \mathrm{~g} / \mathrm{l}$ in the second and third trimester, and $<100 \mathrm{~g} / \mathrm{l}$ in the post-partum period (Pavord et al., 2012). In Indonesia, the majority of anemia in pregnancy was caused by iron deficiency (37.1\%) and bleeding (30.3\%), which can overcome the effects of Low Birth Weight $10.2 \%)$ and abortions (Ministry of Health of Indonesia, 2018). Absorption of iron (Fe) vitamin C is essential. Thus, vitamin C plays a role in the formation of hemoglobin; therefore, it can deal with anemia. Vitamin $\mathrm{C}$ is effortless to be found in Indonesia, such as in some kind of fruits. One fruit that is rich in vitamin $\mathrm{C}$ is sweet orange fruit with a vitamin C content of $49 \mathrm{mg}$. Ascorbic acid (vitamin C) is the most important nutrient in orange juice. The previous study stated that vitamin $\mathrm{C}$ has an effect on $\mathrm{HbA1C}$ among patients with type 2 diabetes mellitus (Dakhale, Chaudhari \& Shrivastava, 2011). Effective management is needed to prevent maternal and pregnancy outcomes. There is inconclusive evidence that prenatal supplementation for IDA improves maternal or infant clinical health outcomes, but supplementation may improve maternal hematologic indices (Dakhale, Chaudhari, \& Shrivastava, 2011). Thus, this study aimed to analyze the effect of iron with a combination of the orange extract on hemoglobin among pregnant women in Nusa Tenggara Barat in 2018.

\section{Methodology}

The design of this study was a quasi-experimental with a control group. This study was conducted in Brang Rea Health Centre, Sumbawa Barat Regency Nusa Tenggara Barat Province Indonesia from January to May in 2018. The population was 30 pregnant women who were anemic. A total population was used to define the sample size. The inclusion criteria were anemic pregnant women and are able to participate in the study, while the exclusion criteria were anemic pregnant women with some diseases such as leukemia, intestinal worms, malaria, pulmonary tuberculosis, mall nutrition, and bleeding. A portable hemoglobinometer (Family $\mathrm{Dr}$. $\mathrm{Hb}$ ) was used to analyze the Hb. Measuring Hb concentration in human blood by a portable hemoglobinometer has shown its specificity (95.8\%) and high negative predictive value (95.8\%) (Tala, Darlan, Tantono, \& Arrasyid, 2017).

The intervention was iron supplementation with orange extract provided to all participants without charge. The intervention was delivered for 30 days. The researcher checked the hemoglobin before the intervention and noted it. The process of extracting orange as follows; (1) squeeze two oranges fruits (100 g) into a glass that is $100 \mathrm{ml}$ without added water and sugar; (2) stir with a tablespoon; (3) drink a glass of orange extract a day with $200 \mathrm{mg}$ of an iron tablet (Ferrous Fumarate) which provided by the Health Centre. It was consumed in the morning after breakfast for 30 consecutive days. After 30 days of intervention, the researcher re-checked the hemoglobin and noted. The data were analyzed using descriptive statistics and inferential statistics. A paired sample t-test was used to analyze the difference of hemoglobin within the group, while an Independent t-test was used to analyze differences of hemoglobin between groups. A normality test was conducted before using inferential statistics. Hemoglobin data of pre-test and post-test in both groups were normal $(p \geq .05)$.

\section{Ethical consideration}

This study has gained the ethical consideration by the ethics committee of Faculty of Health Science Universitas Nasional with the letter-number 994/D/Fikes/XI/2017 and by the Local Development Plan and Research Agency of Sumbawa Barat Regency with the letter-number 070/117/Bappeda Litbang/XI/2017.

\section{Results}

\subsection{Respondents' Anemia Levels}

Table 1. Characteristics of Respondents based on Anemia Levels

\begin{tabular}{cccccc}
\hline \multirow{2}{*}{ No } & Respondents' characteristic & \multicolumn{2}{l}{ Pre-Test } & \multicolumn{2}{c}{ Post-Test } \\
\hline & & $(\mathrm{f})$ & $(\%)$ & $(\mathrm{f})$ & $(\%)$ \\
\hline 1 & Not Anemic & 0 & 0 & 16 & 53.3 \\
2 & Anemic & 30 & 100.0 & 14 & 46.7 \\
\hline & Total & 30 & 100.0 & 30 & 100.0 \\
\hline
\end{tabular}


Table 1 shows that all respondents (100\%) are anemic before received the intervention, and 14 respondents (46.7\%) are anemic after received the intervention.

\subsection{The differences in hemoglobin before and after intervention in the experimental group}

Table 2. The differences in the level of hemoglobin before and after receiving iron with orange extract in the experimental group

\begin{tabular}{clcccc}
\hline No & Hemoglobin & Mean (g/dl) & SD & t-test & $\boldsymbol{p}$ \\
\hline 1 & Pre-test & 9.07 & 0.71 & -21.15 & 0.000 \\
2 & Post-test & 11.57 & 0.47 & & \\
\hline
\end{tabular}

Table 2 shows that the mean of $\mathrm{Hb}$ before the intervention is $9.07 \mathrm{~g} / \mathrm{dl}(\mathrm{SD}=0.71$ ) and the mean of $\mathrm{Hb}$ after the intervention is $11.57 \mathrm{~g} / \mathrm{dl}(\mathrm{SD}=0.47)$. It can be concluded that the Hb level was increased after the intervention. Besides, it can be concluded that there is a significant difference in hemoglobin within-group or before and after the intervention $(p=0.000, t=-21.15)$.

\subsection{The differences of hemoglobin before and after intervention in the control group}

Table 3. The differences in the level of hemoglobin before and after receiving iron without orange extract in the control group

\begin{tabular}{cccccc}
\hline No & Hemoglobin & Mean (g/dl) & SD & t-test & $\boldsymbol{p}$ \\
\hline 1 & Pre-test & 9.75 & 0.57 & -9.27 & 0.001 \\
2 & Post test & 10.6 & 0.54 & & \\
\hline
\end{tabular}

Table 3 shows that the mean of $\mathrm{Hb}$ before intervention is $9.75 \mathrm{~g} / \mathrm{dl}(\mathrm{SD}=0.57)$ and the mean of $\mathrm{Hb}$ after the intervention is $10.6 \mathrm{~g} / \mathrm{dl}(\mathrm{SD}=0.54)$. It can be concluded that the $\mathrm{Hb}$ level was increased after intervention, even though without orange extract. Besides, it can be concluded that there is a significant difference in hemoglobin before and after the intervention $(p=0.001, t=-9.27)$.

\subsection{The differences of hemoglobin between experimental and control group after intervention}

Table 4. The differences of hemoglobin between experiment and control group after intervention

\begin{tabular}{llllll}
\hline No & Group & Mean (g/dl) & SD & t-test & $\boldsymbol{p}$ \\
\hline 1 & Experiment & 11.57 & 0.47 & 5.199 & 0.001 \\
2 & Control & 10.6 & 0.45 & & \\
\hline
\end{tabular}

Table 4 shows the mean difference between groups. The mean of $\mathrm{Hb}$ in the experiment group is $11.57 \mathrm{~g} / \mathrm{dl}(\mathrm{SD}=0.47)$ and the mean of $\mathrm{Hb}$ in the control group is $10.6 \mathrm{~g} / \mathrm{dl}(\mathrm{SD}=0.45)$. It can be concluded that the mean of $\mathrm{Hb}$ in the experimental group was higher than the control group. Furthermore, there is a significant difference in $\mathrm{Hb}$ levels between the experimental and control group $(p=0.001, t=5.199)$.

\section{Discussion}

The results show that all pregnant women were anemic before the intervention. Based on an interview conducted to five pregnant women in Brang Rea Health Center (September, 20th 2018), all pregnant women were lack of knowledge about the benefits of iron and the danger of anemia. The majority of respondents did not know how to consume iron correctly so that this affected the mindset of pregnant women to consume iron with anything that could affect iron absorption. Respondents usually consumed iron with milk and tea or usually 5 minutes after taking iron, so that it can inhibit iron absorption. This is thought to be a factor that can trigger the high incidence of anemia at the Brang Rea Health Center. The previous study has found that poor knowledge regarding anemia and less iron intake is the leading cause of anemia during pregnancy (Sultana, Ara, Akbar, \& Sultana, 2019; Zhang, Rojhani, Gullo-Rivera \& Kwak, 2018).

The results of the independent $t$-test found that there was a significant difference in the hemoglobin between the experimental and control group $(p=0.000)$. The paired $t$-test ( $p$-value $=0.000)$ showed that there was a significant difference in $\mathrm{Hb}$ before and after the administration of iron tablets with sweet orange extract among anemic pregnant women. Orange fruits contained vitamin $\mathrm{C}$, which is useful in absorbing iron. This is consistent with a previous study that found that consumption of non-heme source 
foods with vitamin $\mathrm{C}$ is needed to convert folic acid into an active form, increase iron absorption, and help form connective tissue (Chambial, Dwivedi, Shukla, John \& Sharma, 2013).

Vitamin C plays a role in the formation of hemoglobin, thus accelerating the healing of anemia. Sweet oranges are rich in nutrients, especially vitamin $\mathrm{C}$ and Bioflavonoids, which are essential to prevent bleeding, mental and physical deterioration, and reduce the presence of bruises (Liu, Heying \& Tanumihardjo, 2012). Vitamin C helps in increasing absorbable ferrous iron in iron deficiency anemia (Ems \& Huecker, 2019; He et al., 2018). A previous study found that there was a relationship between vitamin C and hemoglobin (Danefi \& Apriasih, 2020). In contradictive, a survey study conducted by (Purwaningtyas \& Prameswari, 2017) found that there was no relationship between iron and vitamin C with the incidence of anemia in pregnancy (Purwaningtyas \& Prameswari, 2017).

Furthermore, a study (Aminah, 2020) found that there were no correlations between iron and vitamin C intake with hemoglobin levels. The un-significant result might be caused by the compliance of women in consuming iron, and low knowledge regarding anemia and how to consume iron. Compliance with iron consumption is one of the crucial factors related to anemia among pregnant women (Ba et al., 2019; Birhanu, Birarra \& Mekonnen, 2018). Researchers found that some pregnant women consuming iron with sweet tea or milk for reasons to reduce nausea they experienced because of the side effects of iron. This habit can shake the absorption of iron so that it can trigger anemia. Therefore, health workers need to encourage pregnant women to consume iron with orange extract. The vitamin $C$ of the orange extract could help the absorption of iron and increase hemoglobin levels among pregnant women. Finally, it is hoped that anemia will be decreased, and the pregnancy outcome will be improved.

Based on an interview between researcher and midwife who had taken care of respondents, some respondents were malnourished (Brang Rea Health Centre, 2018). A study revealed that iron deficiency could occur due to unbalanced food consumption or disruption of iron absorption, which is one of the factors causing anemia (Steinbicker \& Muckenthale, 2013). This is in accordance with the theory of the causes of the aforementioned anemia. Therefore, pregnant women need to be given education about nutrition needed during pregnancy and the danger of anemia to reduce the incidence of anemia.

Anemia in pregnant women is caused by iron deficiency resulting in a lack of $\mathrm{Hb}$ where iron is one of the constituent elements (Camaschella, 2015). Many factors affect the absorption of ferum, one of which is organic acids, such as vitamin $C$ which significantly helps the absorption of non-heme iron by changing the shape of ferries into ferrous forms. Ferrous forms are more easily absorbed; therefore, it is highly recommended to eat food sources of vitamin C every meal (Almatsier, 2015). This is consistent with research that based on a comparative analysis of the effects of supplementation of iron tablets with and without vitamin $C$ on hemoglobin levels in pregnant women with gestational age 16-32 weeks which found that there are differences in the effect of supplementation of iron tablets with and without vitamin C on hemoglobin levels in pregnant women (Utama, Listiana, \& Susanti, 2013). The lower the women's knowledge about how to consume iron tablets correctly, the higher the chance for anemia, because how to consume iron tablets correctly affects the process of iron absorption, where hemoglobin can increase if women experience absorption of iron. Besides, it will also disturb the nutritional intake of pregnant women. Lastly, education about how to consume iron correctly is the key to improve hemoglobin among pregnant women.

\section{Conclusions}

Consuming iron with orange extract has a significant effect on improving hemoglobin among anemic pregnant women. Pregnant women are suggested to consume daily iron as prescribed by health care workers with orange extract. Health care workers need to educate pregnant women about how to consume iron supplements correctly. A revision of anemia prevention and management guideline which already assigned by the government is needed. Several limitations have been found in this study. There was no control of the quality of oranges as experimental material. Thus similarity in the quality of oranges given to respondents was not known. In addition, there is no analysis of demographic variables. Future study is needed to analyze the effect of iron with orange extract on hemoglobin among pregnant women using randomization and orange quality control.

\section{Acknowledgment}

This study acknowledges Universitas Nasional and Brang Rea Health Centre for support.

\section{References}


Almatsier, S. (2015). Prinsip Dasar Ilmu Gizi edisi ke 9 [Basic Principles of Nutrition], PT. Gramedia Pustaka Utama: Jakarta.

Aminah, C. (2020). Hubungan asupan mikronutrien dengan kadar hemoglobin pada ibu hamil trimester I di Puskesmas Kabupaten Agam [Relationship of micronutrient intake with hemoglobin levels in first trimester pregnant women in the Agam District Health Center], (Doctoral dissertation, Universitas Andalas).

Brang Rea Health Centre. (2018). Monitoring the Local Area of Maternal and Child Health (PWS KIA).

Ba, D. M., Ssentongo, P., Kjerulff, K. H., Na, M., Liu, G., Gao, X., \& Du, P. (2019). Adherence to iron supplementation in 22 sub-Saharan African countries and associated factors among pregnant women: a large population-based study. Current Developments in Nutrition, 3(12), nzz120.

Beard, J. L., Hendricks, M. K., Perez, E. M., Murray-Kolb, L. E., Berg, A., Vernon-Feagans, L., ... \& Tomlinson, M. (2005). Maternal iron deficiency anemia affects post-partum emotions and cognition. The Journal of nutrition, 135(2), 267-272.

Birhanu, T. M., Birarra, M. K., \& Mekonnen, F. A. (2018). Compliance to iron and folic acid supplementation in pregnancy, Northwest Ethiopia. BMC research notes, 11(1), 1-5.

Cantor, A. G., Bougatsos, C., Dana, T., Blazina, I., \& McDonagh, M. (2015). Routine iron supplementation and screening for iron deficiency anemia in pregnancy: a systematic review for the US Preventive Services Task Force. Annals of internal medicine, 162(8), 566-576.

Chambial, S., Dwivedi, S., Shukla, K. K., John, P. J., \& Sharma, P. (2013). Vitamin C in disease prevention and cure: an overview. Indian Journal of Clinical Biochemistry, 28(4), 314-328.

Camaschella C. Iron-deficiency anemia. New England journal of medicine 2015; 372(19): 1832-1843.

Danefi, T., \& Apriasih, H. (2020). Effectiveness of Consumption Iron Tablets with Orange Juice to Increase Haemoglobin Levels in Pregnancy. JURNAL KEBIDANAN, 10(1), 37-42.

Dakhale, G. N., Chaudhari, H. V., \& Shrivastava, M. (2011). Supplementation of vitamin C reduces blood glucose and improves glycosylated hemoglobin in type 2 diabetes mellitus: a randomized, double-blind study. Advances in pharmacological sciences, 2011.

Ekiz E, Agaoglu L, Karakas Z, Gurel N \& Yalcin I. The effect of iron deficiency anemia on the function of the immune system. The Hematology Journal 2005; 5: 579-583.

Ems, T., \& Huecker, M. R. (2019). Biochemistry, iron absorption. In StatPearls [Internet]. StatPearls Publishing.

Haider, B. A., Olofin, I., Wang, M., Spiegelman, D., Ezzati, M., \& Fawzi, W. W. (2013). Anaemia, prenatal iron use, and risk of adverse pregnancy outcomes: systematic review and meta-analysis. $B m j, 346$.

Liu Y, Heying E, \& Tanumihardjo SA. History, global distribution, and nutritional importance of citrus fruits. Comprehensive Reviews in Food Science and Food Safety 2012; 11(6): 530-545.

He, H., Qiao, Y., Zhang, Z., Wu, Z., Liu, D., Liao, Z.,Yin, D., \& He, M. (2018). Dual action of vitamin C in iron supplement therapeutics for iron deficiency anemia: prevention of liver damage induced by iron overload. Food \& function, 9(10), 5390-5401.

Ministry of Health of Indonesia. (2018). Profil kesehatan Indonesia tahun 2018 [Indonesia Health Profile 2018].

Mei, Z., Cogswell, M. E., Looker, A. C., Pfeiffer, C. M., Cusick, S. E., Lacher, D. A., \& Grummer-Strawn, L. M. (2011). Assessment of iron status in US pregnant women from the National Health and Nutrition Examination Survey (NHANES), 1999-2006. The American journal of clinical nutrition, 93(6), 1312-1320.

Steinbicker, A. U., \& Muckenthaler, M. U. (2013). Out of balance-systemic iron homeostasis in iron-related disorders. Nutrients, 5(8), 3034-3061.

Purwaningtyas, M. L., \& Prameswari, G. N. (2017). Faktor kejadian anemia pada ibu hamil. HIGEIA (Journal of Public Health Research and Development), 1(3), 43-54.

Utama TA, Listiana N, \& Susanti D. Perbandingan zat besi dengan dan tanpa vitamin c terhadap kadar hemoglobin wanita usia subur. Kesmas: National Public Health Journal 2013; 7(8): 344-348.

Stevens, G., Finucane, M., De-Regil, L., Paciorek, C., Flaxman, S., Branca, F., Pena-Rosas J., Bhuta Z., \& Ezzati, M. (2013). Global, regional, and national trends in total and severe anaemia prevalence in children and pregnant and non-pregnant women. Lancet Global Health, 1(1), e16-e25.

Pavord, S., Myers, B., Robinson, S., Allard, S., Strong, J., Oppenheimer, C., \& British Committee for Standards in Haematology. (2012). UK guidelines on the management of iron deficiency in pregnancy. British journal of haematology, 156(5), 588-600.

Sultana, F., Ara, G., Akbar, T., \& Sultana, R. (2019). Knowledge about Anemia among Pregnant Women in Tertiary Hospital. Medicine Today, 31(2), 105-110. 
Tala, Z. Z., Darlan, D. M., Tantono, J., \& Arrasyid, N. K. (2017). Accuracy in measuring hemoglobin concentration using portable hemoglobinometer method.

Zhang, Q., Rojhani, A., Gulló-Rivera, A., \& Kwak, S. (2018). Prevalence and knowledge of anemia among pregnant women enrolled in Women, Infants and Children supplemental food program. Nutrition \& Food Science. 